\title{
Egészségfejlesztési konferenciák anno és most
}

\author{
Health promotion conferences then and now
}

Szerző: Bíró Éva, Mátyás Gabriella $\bowtie$

Debreceni Egyetem, Népegészségügyi Kar, Megelőző Orvostani Intézet, Egészségfejlesztési Tanszék

Beküldve: 2019. 12. 14.

doi: 10.24365/ef.v60i5.550

Kulcsszavak: egészségfejlesztés; egészségfejlesztési konferencia; jubileum

Keywords: health promotion; health promotion conference; jubilee

\begin{abstract}
„A marék liszt kézről-kézre adva elfogy, még mielőtt a célhoz érne" - írta Füsti Molnár Sándor az 1960 decemberében megrendezett Egészségügyi felvilágosítás I. országos értekezletéről írt beszámolójában, utalva arra, hogy a Köjál - vagyis a Közegészségügyi Járványügyi Állomás - keretein belül múködő egészségügyi felvilágosítási csoport munkáját nagyban nehezíti a területi hálózat hiánya. ${ }^{1}$ Ezzel a konferenciával kezdődött el a hazai szakmai életben azon találkozók sora, amelyeken az egészségügyi felvilágosítás (később egészségnevelés) területén dolgozók rendszeresen megosztották egymással tapasztalataikkal. Ugyanakkor az európai szocialista országok első egészségügyi felvilágosítási szimpozionjának ötlete és megszervezése is Magyarországhoz köthető 1964-ben, ahol részben az oktatás és továbbképzés, részben pedig a nemzetközi együttmúködés és tudományos kutatás került a fókuszba. ${ }^{2}$
\end{abstract}

Az Egészségügyi Világszervezet (World Health Organization, WHO) Alma-Atai Alapellátási Konferenciája és az „Egészséget mindenkinek” mozgalma volt az egészségfejlesztést középpontba helyező irányzatok kiindulópontja. Kiemelt fontosságot tulajdonítottak az egészséget determináló tényezők ágazatközi kezelésének, valamint az érintettek bevonásával és részvételével történő tervezésnek és kivitelezésnek. Az irányzat a betegségek kezeléséről egyre inkább a betegségek kialakulásában szerepet játszó tényezők befolyásolására helyezte a hangsúlyt, amelynek alapelvei a WHO által szervezett későbbi nemzetközi egészségfejlesztési konferenciák záródokumentumaiban kristályosodtak ki. ${ }^{3}$ 1986-ban a kanadai Ottawában került megrendezésre az 1 . nemzetközi egészségfejlesztési konferencia, melynek záródokumentuma Ottawai Karta néven vált ismertté és az egészségfejlesztés sarokkövévé. Ebben vettették először papírra az egészség alapfeltételeit, definiálták az egészségfejlesztés fogalmát, valamint meghatározták annak fő tevékenységi területeit és stratégiáit. 4,5

Az 1988-ban Adelaide-ben rendezett 2. nemzetközi egészségfejlesztési konferencia ajánlásai az egészséget támogató közpolitikára összpontosítottak. A politika azért kapott kiemelt szerepet, mert alapvető jelentőségű az egészség alapfeltételeinek biztosításához és az egészségfejlesztés másik négy fő tevékenységét elősegítő jogszabályi, társadalmi és épített környezet megteremtéséhez. Az egészséget támogató politika lehetővé teszi - vagy optimális esetben megkönnyíti - az emberek számára az egészséges választást; kialakítja és javítja a társadalmi és a fizikai környezetet; figyelembe veszi és monitorozza a politikai döntések egészségre gyakorolt hatását, ideértve az (egészség)egyenlőtlenségek csökkentését is. ${ }^{6,7}$

Az előző konferenciák szellemiségét folytatva rendezték meg 1991-ben Sundsvallban a 3. nemzetközi egészségfejlesztési konferenciát, melynek fő témája az egészséget támogató környezet volt. A környezet kifejezést ez a konferencia a lehető legtágabban értelmezte, így például beleértette a természeti és épített környezetet, a szociális, 
spirituális, gazdasági, valamint politikai környezetet is. Ezek egymással szoros kapcsolatban állnak, és ahhoz, hogy a környezet e dimenzióira irányuló akciók sikeresek legyenek, azokat össze kell hangolni a különböző - helyi, regionális, országos, globális szinteken. Minden szektorban szükség van az egészséget támogató környezet megteremtését támogató kezdeményezésekre, melyek végrehajtása a közösség, a civil szervezetek, a kormányok, illetve a nemzetközi szervezetek feladata. Az egészséget támogató környezet kialakítása során az egészségegyenlőség alapvető prioritásként kezelendő, illetve tekintettel kell lenni az élólények egymásra utaltságára, és kiemelten erősíteni szükséges a társadalmi cselekvéseket, a globális perspektíva szem előtt tartásával és a globális felelősség vállalásával. ${ }^{8,9}$

Az egészségmegőrzés 21. századi lehetőségeit vizsgálta a 4. nemzetközi egészségfejlesztési konferencia, amelynek zárásaként adták ki 1997-ben a Dzsakartai Nyilatkozatot. Ebben bemutatták az egészség meghatározói közül azokat, amelyek új kihívásokként szerepelhetnek. Így az egészség előfeltételei közé bekerült a társadalmi biztonság és az emberi kapcsolatok, a nők jogai, és az emberi jogok tiszteletben tartása. Új egészségproblémák jelentek meg, illetve kaptak nagyobb hangsúlyt, mint például a mentális betegségek; és változtak az egészséget meghatározó tényezők is, amelyek körébe bekerült a médiához való hozzáférés és a kommunikációs technológiák elterjedése. A Nyilatkozat szerint az Ottawai Konferencia óta összegyűjtött bizonyítékok alátámasztják az egészségfejlesztés hatékonyságát az egészségegyenlőtlenségek csökkentésében. Az is igazolódott, hogy az átfogó megközelítések a leghatékonyabbak; a mindennapi élet színterei alkalmasak ezek megvalósítására, továbbá a fenntarthatósághoz alapvető a közösségi részvétel, amit az egészséggel kapcsolatos tudás erősít. A dokumentum szerint a 21. században az egészségmegőrzés prioritásai között szerepel a társadalmi felelősségtudat fejlesztése, a beruházások növelése, a partneri kapcsolatok megszilárdítása és kiterjesztése az egészség érdekében, a közösségi kapacitások fejlesztése és az egyén megerősítése, valamint az egészségfejlesztés infrastruktúrájának biztosítása. A globális egészségfejlesztés előmozdítása érdekében fontos egy, a WHO által vezetett egészségfejlesztési szövetség létrehozása. ${ }^{10,11}$
A soron következő, 5., nemzetközi egészségfejlesztési konferencia 2000-ben Mexikóvárosban került megrendezésre; mottója az (egészség)egyenlőtlenségek megszüntetése volt. Ennek zárásaként az alábbi pontokat tartalmazó nyilatkozatot tették: az egészség fejlesztését alapvető prioritásként kell kezelni a helyi, regionális, országos és nemzetközi döntésekben és programokban; fontos, hogy minden ágazat és a civil társadalom is aktívan részt vegyen az egészség fejlesztését célzó tevékenységekben, amelyek erősítik és kiterjesztik az egészség érdekében létrehozott együttmúködéseket; támogatni kell a nemzeti szintű egészségfejlesztési tervek elkészítését; valamint az egészség fejlesztését elősegítő országos és nemzetközi hálózatokat szükséges létrehozni. ${ }^{12,13}$

A 2005-ben megtartott 6. nemzetközi konferencia célja az volt, hogy megvizsgálják, mennyiben befolyásolja a globalizáció az egészségfejlesztési tevékenységeket, mivel az Ottawai Karta kiadása óta jelentős változások történtek az egészséget meghatározó tényezők globális összefüggéseinek tekintetében. A levont következtetéseket a „Bangkoki Karta az egészségfejlesztésért egy globalizálódó világban" tartalmazza. A Karta szerint kiemelt fontosságú a közösségek megerősítése, az egészség javítása és az egészségegyenlőség elérését célzó szakpolitikák középpontba állítása. Az egészséget alapvetően befolyásoló tényezők közé a növekvő egyenlőtlenségeket, a fogyasztás és a kommunikáció új formáit, az elüzletiesedést, a globális környezeti változásokat, valamint az urbanizációt sorolták. A globalizáció ugyanakkor lehetőségeket is nyújt az egészség fejlesztésére az információs és kommunikációs technológiák révén; illetve segíthet a világméretú kormányzás és a tapasztalatcserék bővítése is. Az egészség fejlesztése érdekében megvalósítandó legfontosabb kötelezettségek: az egészségfejlesztés a globális fejlesztési menetrend, valamint a közösségek és a civil társadalom figyelmének középpontjába kerüljön; a kormányzat egésze számára alapvető felelősség, a jó vállalati gyakorlat számára pedig követelmény legyen. ${ }^{14,15}$

A Nairobiban 2009-ben megrendezett 7. nemzetközi egészségfejlesztési konferencia záródokumentumában azt hangsúlyozták, hogy az egészségfejlesztés hatékonyságára vonatkozó bizonyítékok és a korábbi nemzetközi nyilatkozatok ellenére az egészségfejlesztés céljainak széleskörű megvalósítása még várat magára. Három területen neveztek 
meg hiányosságokat, így a bizonyítékoknak a gyakorlatba ültetése, a politikai döntéseknél az egészség társadalmi determinánsainak a figyelembe vétele, és az egészségügyi rendszereknek az egészségfejlesztés irányába történő elmozdítása. Éppen ezért fontos a kormányok népegészségügyi felelősségvállalása, melynek feltételei az ágazatközi együttmúködés, a lakosság bevonása, és partnerség kiépítése. Prioritásként kell kezelni a társadalmi igazságosság és esélyegyenlőség elősegítését, az ezt megalapozó társadalmi és gazdasági egészség-meghatározók kedvező irányú befolyásolását, a fejlesztési célok megfogalmazását a kapacitások növelése és a hatékony irányítás kialakítása érdekében, valamint az egészségmúveltség fejlesztését. ${ }^{16}$ Az előző konferenciák szellemiségét követve rendezték meg 2013-ban Helsinkiben a 8. nemzetközi egészségfejlesztési konferenciát. ${ }^{17} \mathrm{~A}$ rendezvény az „Egészség minden szakpolitikában” (Health in all policies) megközelítés köré szerveződött. Ennek fő jellemzője az egészség szempontjainak érvényesítése a politikaformálás minden szintjén, azaz a döntéseknek az egészségügyi rendszerre, az egészséget befolyásoló tényezőkre és a jóllétre gyakorolt hatásának figyelembe vétele, valamint annak hangsúlyozása, hogy a lakosság egészségi állapotának kialakításban meghatározó szerep jut az egészségügyön kívül más ágazatoknak is.

Az Ottawai Karta aláirása után 30 évvel, 2016-ban került megrendezésre a 9. nemzetközi egészségfejlesztési konferencia Sanghajban, melynek központi témája a fenntartható fejlődés volt az Egyesült Nemzetek Szövetsége (ENSZ) által 2015-ben elfogadott új globális fenntartható fejlődési keretrendszerrel összhangban. ${ }^{18,19}$ A Sanghaji Deklaráció kimondja, hogy az egészség és jóllét elengedhetetlen a fenntartható fejlődési célok (sustainable development goals) eléréséhez. Ehhez 3 fő cselekvési területet jelöl ki: az első a megfelelő kormányzás, azaz az egészséget szolgáló politikai döntéshozás. Ennek keretein belül javasolja többek közt az egészségtelen termékek adóztatásának és törvényi szabályozásának szigorítását, illetve az általános egészségbiztosítás bevezetését. A második a helyi akciók megvalósítása a városok és közösségek bevonásával. Végül pedig az egészségmúveltség fejlesztésén keresztül a lakosság felhatalmazása, döntésképességének növelése.
Jubileumi megemlékezés a 60 éves Egészségfejlesztésről

Vilmon Gyula-nívódíjas folyóiratunk idén ünnepli fennállásának 60. évfordulóját. A lap Egészségügyi Felvilágosítás címmel, az Egészségügyi Minisztérium Egészségnevelési Központja szervezési és módszertani tájékoztatójaként indult, első főszerkesztői Vilmon Gyula és Métneki János voltak. Az 1963-tól már kéthavonta megjelenő folyóirat 1975-ig Népegészségügy, 1976-tól 2003-ig Egészségnevelés, 2004 óta Egészségfejlesztés nevet viseli. Folyóiratunk büszke arra, hogy a hazai népegészségügyi szakfolyóiratok közül elsőként, csak szakbírálaton átesett (peer-reviewed) eredeti közleményeket jelentet meg, az egészségfejlesztés területéről származó legfrissebb hírek, fejlesztések, érdekességek, beszámolók, vélemények és megvitatásra érdemes kérdések felvetése mellett.

Folyóiratunk jubileumi konferenciájára a budapesti Semmelweis Egészségfejlesztési Központban, az I. Hatékony Egészségfejlesztési Konferencia keretében került sor 2019. november 30-án. A rendezvényt Horváth Ildikó, az Emberi Erőforrások Minisztériumának egészségügyért felelős államtitkára nyitotta meg, aki méltatta a folyóirat eredményeit, valamint kiemelte az egészségfejlesztés fontosságát a magyar lakosság egészségi mutatóinak javításában és a népegészségügyi beavatkozások területén. $\mathrm{Az}$ érdeklődő közönség számára ezután Vitrai József, az Egészségfejlesztés jelenlegi főszerkesztője számolt be a folyóirat aktuális helyzetéről, kiemelve, hogy lapunk a sokszínűségre törekszik, így a megjelenő cikkeket nemcsak az egészségfejlesztéssel foglalkozó szakemberek és döntéshozók figyelmébe ajánljuk és készítjük, hanem a szakterület iránt érdeklődő laikusok számára is, illetve az oktatási, a szociális vagy egyéb ágazatok egészségfejlesztési tevékenységet is végző szakemberei, továbbá a közgazdaságtan, szociológia, média, urbanisztika képviselőinek is. Vitrai József beszámolójában kiemelte, hogy a lap 2016-os online megjelenése óta folyamatosan növekszik az olvasók tábora: a folyóirat látogatottsági statisztikája havonta tartósan 10 ezer felett van, illetve naponta 300 feletti a látogatások száma.

Ezután a konferencia programjában az olvasói érdeklődésre leginkább számot tartó cikkek előadása szerepelt, melyek a következők voltak: 
- OKOSTÁNYÉR ${ }^{\circledR}$ - új táplálkozási ajánlás a hazai felnőtt lakosság számára (előadó: Szűcs

Zsuzsanna),

- Egészséges életmóddal kapcsolatos kutatások a hazai iskolákban (előadó: Járomi Éva),

- Magyarország népegészségügyi rendszere és egészségfejlesztéssel foglalkozó szervezetei (előadó: Túri Gergő),

- Egészségfejlesztési Irodák hálózata (előadó: Bezzegh Péter),

- Pánrezisztens kórokozók által okozott többlethalálozás: mi áll valójában a szakirodalomban? (előadó: Gajdács Márió).

A résztvevőknek az előadások után alkalmuk volt kérdéseiket feltenni az előadóknak az elhangzottakkal kapcsolatban. Ezt kerekasztal-beszélgetés követte Solymosy József Bonifácz, korábbi főszerkesztő vezetésével, melynek témája a folyóirat múltja és jövője volt. A kerekasztal-beszélgetés során a résztvevőknek lehetősége nyílt megismerni a lap jelenlegi szerkesztőit, illetve kötetlen formában elbeszélgetni velük.
Végül a konferencia záróakkordjaként a szerkesztőség az Egészségfejlesztés folyóirat szakmai színvonalának emeléséért végzett munkájáért díjazásban részesítette Simon Tamást, Solymosy József Bonifáczot, Réthy Lajost, Csizmadia Pétert, Varsányi Pétert, Németh Évát, Formanek-Balku Esztert és Járomi Évát.

\section{Támogatás}

A nemzetközi konferenciákra vonatkozó információk a Bevezetés az egészségfejlesztésbe tananyag elkészítése során kerültek összegyűjtésre, melyet "Az élettudományi-, klinikai felsőoktatás gyakorlatorientált és hallgatóbarát korszerűsítése a vidéki képzőhelyek nemzetközi versenyképességének erősítésére" TÁMOP 4.1.1.C-13/1/KONV-20140001 számú projekt támogatta. A projekt az Európai Unió támogatásával, az Európai Szociális Alap társfinanszírozásával valósult meg.

\section{HIVATKOZÁSOK}

\footnotetext{
${ }^{1}$ Füsti Molnár S. Az egészségügyi felvilágosítás I. országos értekezlete. Egészségügyi Felvilágosítás, 1961., 2. évf. 1. szám pp. 1-3.

2 Füsti Molnár S. Beszámoló az európai szocialista országok első egészségügyi felvilágosítási szimpozionjáról Egészségügyi Felvilágosítás, 1965., 6. évf. 1. szám pp. 37-40.

${ }^{3}$ Kósa K. Van-e hazai közmegegyezés arról, hogy mi az egészségfejlesztés? Népegészségügy, 2010., 88. évf. 1. szám. pp. 3-10.

${ }^{4}$ Kishegyi J, Makara P. (szerk): Az egészségfejlesztés alapelvei. Az egészségfejlesztés alapvető nemzetközi dokumentumai. Egészségfejlesztési módszertani füzetek. Országos Egészségfejlesztési Intézet, 2004. pp. 9-14. http://regi.oefi.hu/modszertan1.pdf (Elérve: 2019. 12. 14.)

${ }_{5}$ The Ottawa Charter for Health Promotion. First International Conference on Health Promotion, Ottawa, 21 November 1986. http://www.who.int/healthpromotion/conferences/previous/ottawa/en/ (Elérve: 2019. 12. 14.)

${ }^{6}$ Kishegyi J, Makara P. (szerk): Az egészségfejlesztés alapelvei. Az egészségfejlesztés alapvető nemzetközi dokumentumai. Egészségfejlesztési módszertani füzetek. Országos Egészségfejlesztési Intézet, 2004. pp. 15-22. http://regi.oefi.hu/modszertan1.pdf (Elérve: 2019. 12. 14.)

${ }^{7}$ Adelaide Recommendations on Healthy Public Policy. Second International Conference on Health Promotion, Adelaide, South Australia, 5-9 April 1988. http://www.who.int/healthpromotion/conferences/previous/adelaide/en/ (Elérve: 2019. 12. 14.)

${ }^{8}$ Kishegyi J, Makara P. (szerk): Az egészségfejlesztés alapelvei. Az egészségfejlesztés alapvető nemzetközi dokumentumai. Egészségfejlesztési módszertani füzetek. Országos Egészségfejlesztési Intézet, 2004. pp. 23-28. http://regi.oefi.hu/modszertan1.pdf (Elérve: 2019. 12. 14.)

${ }^{9}$ Sundsvall Statement on Supportive Environments for Health. Third International Conference on Health Promotion, Sundsvall, Sweden, 9-15 June 1991. http://www.who.int/healthpromotion/conferences/previous/sundsvall/en/index3.html (Elérve: 2019. 12. 14.)

${ }^{10}$ Kishegyi J, Makara P. (szerk): Az egészségfejlesztés alapelvei. Az egészségfejlesztés alapvető nemzetközi dokumentumai. Egészségfejlesztési módszertani füzetek. Országos Egészségfejlesztési Intézet, 2004. pp. 29-34. http://regi.oefi.hu/modszertan1.pdf (Elérve: 2019. 12. 14.)
} 


\footnotetext{
11 Jakarta Declaration on Leading Health Promotion into the 21st Century. The Fourth International Conference on Health Promotion: New Players for a New Era - Leading Health Promotion into the 21st Century, Jakarta, from 21 to 25 July 1997. http://www.who.int/healthpromotion/conferences/previous/jakarta/declaration/en/ (Elérve: 2019. 12. 14.) 12 Kishegyi J, Makara P. (szerk): Az egészségfejlesztés alapelvei. Az egészségfejlesztés alapvető nemzetközi dokumentumai. Egészségfejlesztési módszertani füzetek. Országos Egészségfejlesztési Intézet, 2004. pp. 35-36. http://regi.oefi.hu/modszertan1.pdf (Elérve: 2019. 12. 14.)

${ }_{13}$ Mexico Ministerial Statement for the Promotion of Health: From Ideas to Action. Fifth Global Conference on Health Promotion, Mexico City, June 5th, 2000. http://www.who.int/healthpromotion/conferences/previous/mexico/en/ (Elérve: 2019. 12. 14.)

${ }^{14}$ Bangkoki charta az egészségfejlesztésért a globalizált világban. Egészségfejlesztés, XLVI. évfolyam, 2005. 4. szám pp. 3-5.

${ }^{15}$ Bangkok Charter for Health Promotion in a globalized world. The 6th Global Conference on Health Promotion. Bangkok, 7-11 August 2005. http://www.who.int/healthpromotion/conferences/6gchp/en/ (Elérve: 2019. 12. 14.)

${ }^{16}$ Promoting health and development: closing the implementation gap. Nairobi Call to Action. The 7th Global Conference on Health Promotion. Nairobi, Kenya 2009. October 26-30. http://www.who.int/healthpromotion/conferences/7gchp/overview/en/(Elérve: 2019. 12. 14.)

17 The Helsinki Statement on Health in All Policies. The 8th Global Conference on Health Promotion, Helsinki, Finland, 10-14 June 2013. http://www.who.int/healthpromotion/conferences/8gchp/8gchp helsinki statement.pdf?ua=1 (Elérve: 2019. 12. 14.)

${ }^{18}$ Shanghai Declaration on promoting health in the 2030 Agenda for Sustainable Development. The 9th Global Conference on Health Promotion, Shanghai, China, 21-24 November 2016. http://www.who.int/healthpromotion/conferences/9gchp/shanghai-declaration.pdf?ua=1 (Elérve: 2019. 12. 14.)

${ }_{19}$ Transforming our world: the 2030 Agenda for Sustainable Development. United Nations, 21 October 2015. https://sustainabledevelopment.un.org/post2015/transformingourworld (Elérve: 2019. 12. 14.)
} 